\title{
A CASE OF ATYPICAL HEMOLYTIC UREMIC SYNDROME IN A PATIENT WITH PREECLAMPSIA
}

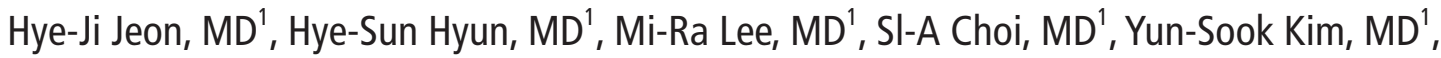 \\ Dong-Han Bae, MD', Hui Jun Kim, MD² \\ Departments of ${ }^{1}$ Obstetrics and Gynecology, ${ }^{2}$ Laboratory Medicine, Soonchunhyang University Cheonan Hospital, Soonchunhyang University College of Medicine, \\ Cheonan, Korea
}

\begin{abstract}
Atypical hemolytic uremic syndrome (HUS) in adults is a life-threatening disorder characterized by microangiopathic hemolytic anemia, thrombocytopenia and acute renal failure, which is not related to Escherichia coli. This disease occurs under the condition of certain stresses, including pregnancy related disease like as preeclampsia, placental abruption, and amniotic fluid embolism. Heparin and plasma exchange has proven to be an effective treatment for HUS and it has decreased the mortality of this illness. We experienced a case of 34 weeks' pregnant woman with preeclampsia who presented with hematuria, oliguria, hemolytic anemia and thrombocytopenia. We performed emergency cesarean section due to fetal distress. After operation, she was treated with transfusion of packed red blood cell, parenteral albumin, and anticoagulant. After seven days from the operation, the sign of hematuria disappeared and her renal function partially recovered. We describe this case with a brief review of the literature.
\end{abstract}

Keywords: Atypical hemolytic uremic syndrome; Pre-eclampsia; Pregnancy

1955년 Gasser 등[1]에 의하여 처음 보고된 용혈성요독증후군은 미 세혈관성 용혈성 빈혈, 혈소판감소증, 신장의 미세 혈류성 혈소판 혈전 에 의해 발생하는 급성 신부전증을 특징으로 하는 면역질환으로, 전형 적인 요독증후군은 대개 소아에서 대장균에 의한 혈성설사와 연관되어 발생한다. 비전형적인 용혈성요독증후군은 전체의 $10 \%$ 를 차지하는 질 환으로 대장균에 의한 shiga 독소와 무관하게, 억제되지 않는 보체계의 활성화로 인해 발생하며, 사망률이 $25 \%$ 에 이르며 불량한 예후를 보인 다22]. 비전형적인 형태의 원인으로는 임신, 출산, 경구피임약 복용, 악 성 고혈압, 경피증과 전신성 루프스 등의 결체조직질환 등이 알려져 있 다[3]. 성인에서는 대부분 여성에서 발생하며, 출혈이나 임신중독증, 태 반박리, 양수색전증과 같은 임신 합병증과 관련되고, 산모에서 발생하는 급성 신부전의 한 원인으로서 주로 분만 후 48시간에서 10 주 사이에 발 생하며, 정확한 발생 빈도에 대한 보고는 없지만 드문 질환으로 알려져 있다. Coratelli 등[4]와 Lazebnik 등[5]이 임신과 관련된 용혈성요독증후 군을 보고하였고, 국내에서는 Shin 등[6]이 정상분만 후 발생한 용혈성 요독증후군 1예, Kim 등[7]이 인공유산 후 발병된 용혈성요독증후군 1 예 등을 보고하였으나, 아직 임신 중에 발생한 용혈성요독증후군에 대 한 보고는 없다. 저자들은 임신 34주에 임신중독증 임신부에 발생한 비 전형적인 용혈성요독증후군 1 예를 경험하여 치료하였기에 문헌 고찰과 함께 보고하는 바이다.

\section{증 례}

환 자: 이ㅁㅣㅣ(37세)

산과력: 2-0-0-2, 16년전과 14년전에 2회의 질식분만을 하였고, 분만 당시 당뇨나 혈압 등은 없었다고 한다.

월경력: 14 세에 초경을 시작하여 28일 주기로 규칙적이고 기간은 7일 이었으며, 양은 중등도이었고 월경통은 없었다.

주소 및 현병력: 임신 34주 4일로 내원 전일부터 갑자기 소변이 거의 나오지 않고, 혈뇨 소견 보여 본원 외래 처음 방문하였다. 최근 설사나

Received: 2011. 6.26. Accepted: 2011. 8. 1.

Corresponding author: Yun-Sook Kim, MD

Department of Obstetrics and Gynecology, Soonchunhyang University Cheonan Hospital, Soonchunhyang University College of Medicine, 23-20 Bongmyeong-dong, Cheonan 330-721, Korea Tel: +82-41-570-2150 Fax: +82-41-571-7887

E-mail:drsook@schmc.ac.kr

This is an Open Access article distributed under the terms of the Creative Commons Attribution Non-Commercial License (http://creativecommons.org/licenses/ by-nc/3.0/) which permits unrestricted non-commercial use, distribution, and reproduction in any medium, provided the original work is properly cited.

Copyright $\odot$ 2011. Korean Society of Obstetrics and Gynecology 


\section{KOREAN JOURNAL OF OBSTETRICS \& GYNECOLOGY}

Hye-Ji Jeon, et al. Atypical hemolytic uremic syndrome in a patient with preeclampsia

열이 난 적은 없었다고 한다. 타병원 산부인과에서 시행한 산전진찰에 서 임신 초기부터 혈압이 높았으나 다른 검사에서 이상은 없었고, 혈압 약은 복용하지 않았다고 한다. 임신 16주 쿼드검사 정상이어서 양수검 사는 시행하지 않았으며, 임신성 당뇨검사 정상이었다고 한다. 외래에서 시행한 초음파에서 태아는 평균 32주 4일 크기로 주수보다 2주 작게 측 정되었으나, 양수양은 정상 범위였고, 태동검사에서 반응성 소견 보였 다. 환자 추가검사 위해 내원 당일 바로 입원하였다.

과거력: 환자는 외상의 기왕력, 약물 복용력, 면역억제제 복용력 등 전 혀 없었다. 이전 출산 시에는 고혈압이나, 임신중독증은 없었고, 이번 임 신 초기부터 혈압이 높았으나 치료를 받지는 않았다고 한다.

가족력과 수술력: 특이 소견 없었다.

신체검사 소견: 입원 당시 신체 검진에서 혈압 $170 / 110 \mathrm{~mm} \mathrm{Hg}$, 맥박 84 회/분, 호흡수 20 회/분, 체온 $36.8^{\circ} \mathrm{C}$ 이었고 의식은 명료하였다. 흉부 소견에서 호흡음은 깨끗하였고, 심박동은 규칙적이었으며, 심잡음은 들 리지 않았다. 결막은 창백하였고, 하지에는 경한 함몰 부종이 있었고, 피 부의 발진, 자반, 점상 출혈은 보이지 않았다.

검사실검사 소견: 혈액검사에서 혈색소는 $8.0 \mathrm{~g} / \mathrm{dL}(12.0-16.0 \mathrm{~g} / \mathrm{dL})$ 로 빈혈 소견 보였으며, 백혈구 $12,030 / \mathrm{mm}^{3}$ 는 정상, 혈소판은 $54,000 /$ $\mathrm{mm}^{3}\left(130-400 / \mathrm{mm}^{3}\right)$ 으로 혈소판감소증 소견 보였고, prothrombin time (PT) $10.8 \mathrm{sec}$ (범위, 9.8-12.4 sec), activated partial thromboplastin time (aPTT) $26.1 \mathrm{sec}$ (범위, 20.4-36.7 sec)로 정상 범위였다. 생화 학검사에서 protein $5.2 \mathrm{~g} / \mathrm{dL}$ (범위, 5.8-8.1 g/dL), albumin $2.8 \mathrm{~g} / \mathrm{dL}$ (범위, 3.1-5.2 g/dL)로 경한 감소 소견 보였고, total bilirubin $0.7 \mathrm{mg} /$ $\mathrm{dL}$ (범위, 0.2-1.2 mg/dL)이었고, aspartate aminotransferase (AST) $38 \mathrm{IU} / \mathrm{L}$ (범위, 0-40 IU/L), alanine aminotransferase (ALT) $33 \mathrm{IU} /$ L (범위, 0-40 IU/L)로 정상이었고, Alkaline phosphatase (ALP) 45 IU/L (범위, 39-117 U/L )는 임신으로 인한 상승 소견 보였다. Urea nitrogen (BUN) $18.7 \mathrm{mg} / \mathrm{dL}$ (범위, 8.0-12.0 mg/dL), creatinine (Cr) $1.6 \mathrm{mg} / \mathrm{dL}$ (범위, $0.6-1.2 \mathrm{mg} / \mathrm{dL}$ )로 증가하여 급성 신부전 소견 보였 다. Lactate dehydrogenase (LDH) 1,406 IU/L (범위, 233-497 IU/L) 로 상승되어 있었고, $\mathrm{Na}^{+} 141 \mathrm{mEq} / \mathrm{L}, \mathrm{K}^{+} 4.0 \mathrm{mEq} / \mathrm{L}, \mathrm{D}-$ dimer $1.4 \mu \mathrm{g} /$ $\mathrm{mL}$ (0-0.5 $\mu \mathrm{g} / \mathrm{mL}$ ), fibrinogen $222.6 \mathrm{mg} / \mathrm{dL}$ (범위, 180-450 mg/dL), antithrombin II 94.2\% (범위, 80-120\%)는 정상 소견 보였고, pro-brain natriureticpeptide $2217 \mathrm{pg} / \mathrm{mL}$ (범위, 0-155 pg/mL)는 상승되어 있었 다. Complement 3 (C3) $111.3 \mathrm{mg} / \mathrm{dL}$ (범위, 90-180 mg/dL), C4 36.9 $\mathrm{mg} / \mathrm{dL}$ (범위, 10-40 mg/dL)로 정상이었으며, 직접 Coombs검사, 간 접 Coombs검사, antinuclear antibody, lupus anti coagulant, antiplatelet antibody는 모두 음성이었다. 요검사에서 요단백은 3+, 적혈구>100/ HPF, 백혈구 50-99/HPF, 요당은 음성이었다. 말초혈액도말검사에서 중등도의 소구성 저염색성 빈혈과 경도의 타원적혈구, 눈물방울세포와 중증의 적혈구부동증(anisocytosis), 변형 적혈구증가증 (poikilocytosis), $20 \%$ 의 분열 적혈구(fragmented red blood cell) 등 미세혈관용혈성 빈 혈 소견 보였다(Fig. 1).

치료 및 경과: 입원 1 시간 동안 소변이 혈뇨로 $10 \mathrm{~mL}$ 가 나왔고, 혈압이 $200 / 130 \mathrm{~mm} \mathrm{Hg}$ 로 증가하면서 항고혈압제에 반응이 없는 악성 고혈압

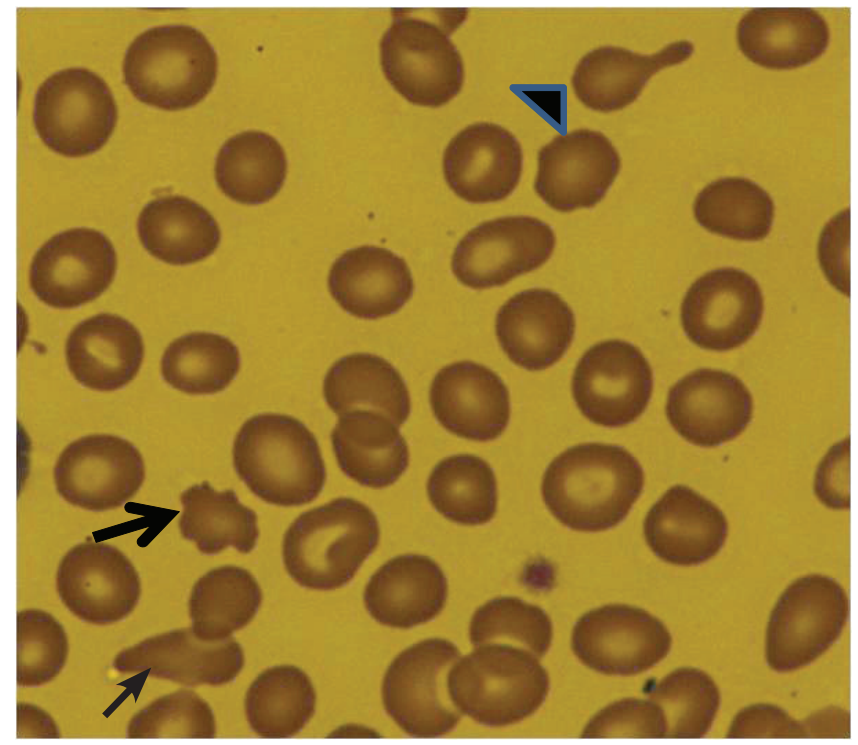

Fig. 1. The peripheral blood smear of the patient showing microcytic, hypochromatic anemia and microangiopathic hemolysis with helmet cells (thin arrow), tear drop cells (arrowhead), and burr cells (thick arrow) (Wright stain, $\times 400)$.

소견 보였다. 입원 당시 반응성을 보이던 태아 심박동이 반복적으로 다 양성 태아심박동수감소(variable deceleration) 소견 보여 응급 제왕절개 수술 결정하였다. 수술 시 복강내에 약 $100 \mathrm{~mL}$ 의 복수 소견이 있었다. 아프가 점수 1 분 7 점, 5 분 9 점의 여아, $1,880 \mathrm{~g}$ 을 분만하였고, 수술 후 중환자실로 이동하였다. 수술 중 20\% albumin과 packed red blood cell 3 pack을 투여하였고, 수술 후 혈압이 계속 $200 / 120 \mathrm{~mm} \mathrm{Hg}$ 소견 보여 nicardipin $100 \mathrm{~mL}$ 를 normal saline100 mL에 섞어서 시간당 $10 \mathrm{~mL} / \mathrm{hr}$ 로 투여하였다. 수술 직 후 혈액 검사에서 혈색소는 $9.0 \mathrm{~g} / \mathrm{dL}$, 혈소판은 $59,000 / \mathrm{mm}^{3}$ 로 증가하여, 추가 수혈은 시행하지 않았다. BUN $19.7 \mathrm{mg} /$ $\mathrm{dL}, \mathrm{Cr} 1.9 \mathrm{mg} / \mathrm{dL}$ 로 더 상승하였으나, 소변은 시간당 $30 \mathrm{~mL}$ 이상 유 지되어 투석과 혈장 교환은 시행하지 않았으며, fraxiparin 2,850 U/0.3 $\mathrm{mL}$ 를 수술 직후부터 수술 7일째까지 투여하였다. 수술 3일째 정상 혈 소판 수치를 회복하였고, 수술 후 7일째 혈뇨는 없어졌으며, 수술 10 일 째 BUN $13.7 \mathrm{mg} / \mathrm{dL}, \mathrm{Cr} 1.2 \mathrm{mg} / \mathrm{dL}$ 로 측정되었다. 수술 5일째 촬영한 복부-골반 컴퓨터단층 촬영에서 간비 종대와 좌측 원위부 요관이 좁아 져 요관 확장과 수신증 소견 보였다. 수술 10일째 심초음파에서 심한 좌 심 비대 소견 보였고, 안과 검사에서 3단계의 중증 고혈압성 망막질환 보였다. 수술 11 일째 퇴원하여 현재 혈압약 복용 중이며 투석은 시행하 지 않고 있다.

\section{고 찰}

1955년 Gasser 등[1]에 의하여 처음 보고된 용혈성요독증후군은 미 세혈관성 용혈성 빈혈, 혈소판감소증, 급성 신부전증 등의 특징적인 


\title{
KOREAN JOURNAL OF OBSTETRICS \& GYNECOLOGY
}

\author{
KJOG Vol. 54, No. 10, 2011
}

임상증상이 나타나는 질환으로, 주로 소아에서 흔하여, 인구 10만 명 당 6.1 예로 발생한다고 보고되고 있으며, 성인에서의 용혈성요독증 후군은 비교적 드문 질환이다. 가장 흔한 원인은 verotoxin을 생성하 는 Escherichia coli (serotype 0157:H7)균이며, 이외 장내세균으로 Shigella dysenteriae type I, Campylobacter jejuni 등도 관련이 있다고 알려져 있다[8]. 성인에서 발생하는 용혈성요독증후군은 감염성 설사 를 동반하는 전형적인 형태보다는 비전형적인 형태가 더 많은데, 비전 형적인 형태는 임신, 출산, 경구 피임약 복용, 악성 종양, mitomycin-C, 5-fluorouracil 등과 같은 화학 요법제, cyclosporine 등과 같은 면역억제 제, 악성 고혈압, 전신성 홍반성 낭창과 전신성 경피증 등의 결체 조직 질환 등에 의해 유발될 수 있고, 유발원인을 찾을 수 없는 예들도 흔하 다[9]. 임신과 관련된 용혈성요독증후군은 산모에서 발생하는 급성 신부 전의 한 원인으로서 출혈이나 자간증, 태반박리, 양수색전증과 같은 임 신 합병증과 관련되고, 이 중 소수에서 신 기능의 저하를 초래하는 것으 로 알려져 있지만, 정상적인 임신을 한 여성에서 이 증후군이 발생될 경 우 예후가 나쁘다[10]. 이 질환의 발병 기전으로는 세균이나 바이러스 에서 분비되는 내독소나 약제 등이 혈관 내피세포의 손상을 일으켜 혈 소판의 응집과 섬유소의 침착을 가져와 좁아진 혈관을 통과하는 적혈구 가 파괴되어 심한 용혈이 생기는 것이다. 정상인에서는 관찰되지 않는 혈관 내피세포에 대한 보체 결합 항체가 발견되고 신생검조직에서 면역 글로불린과 보체가 침착되어 있고, 일시적인 저보체혈증이 발생하는 것 으로 보아 면역학적인 기전에 의한 조직 손상도 중요한 기전으로 생각 된다. 임신과 연관된 용혈성요독증후군의 정확한 병인에 대해서는 아직 밝혀지지 않았지만, 감염이나 에스트로겐의 영향 그리고 프로스타사이 클린의 결핍 등에 의한 미세혈관내의 혈전 형성과 함께 이로 인한 적혈 구의 외상성 파괴로 인한 용혈성 빈혈 및 혈소판감소증이 그 원인으로 가정되고 있다[11].

이 증후군은 전형적인 임상 양상과 함께 검사소견에서 급성 신부전, 미세혈관병증성 용혈성 빈혈, 혈소판 감소, $\mathrm{LDH}$ 의 증가, 망상 적혈구의 증가, haptoglobin 감소 등이 보이면 진단이 가능하다. 다수의 환자는 수 혈이 요할 정도로 심한 빈혈과 혈소판감소증이 나타나며, 혈청의 섬유 소원 수치와 응고검사는 대부분 정상이다. 본 증례에서는 내원 시 혈색 소 $8.0 \mathrm{~g} / \mathrm{dL}$, 혈소판 $54,000 / \mathrm{mm}^{3}$, LDH 1,406 IU/L, BUN/Cr $18.7 / 1.6$ $\mathrm{mg} / \mathrm{dL}$, fibrinogen $222.6 \mathrm{mg} / \mathrm{dL}$ 그리고 말초 혈액도말검사에서 미세혈 관병증성 용혈성 빈혈 소견을 보여 진단이 되었다.

진단이 불확실한 경우는 신장조직검사를 실시하는 경우도 있으나 심 한 혈소판감소증과 고혈압 등이 동반되기 때문에 조직 검사 후의 합병 증 발생에 주의하여야 한다. 또한 조직검사는 채취된 부위에서 혈관 내 혈전이 발견되지 않을 수도 있어 조직학적 소견이 진단에 필수적인 것 은 아니다. 용혈성요독증후군은 조직 병리학적으로 두 가지 다른 양상 으로 나타나는데, 설사와 관계 있는 형태에서는 주로 사구체 모세혈관 과 소동맥의 괴사가 발생하지만 이 경우는 원상회복이 가능하다. 다른 형태인 성인의 경우에서와 같은 비전형적인 경우 소동맥과 작은 동맥의 맥관 내막 증식과 혈관구경의 협착이 발생하며, 이 경우 원상회복이 어 려워 예후가 나쁜 것으로 되어 있다[12]. 본 증례에서는 제왕절개 수술
후 보존적 치료를 실시하였으며 급성 신부전증이 호전되어 조직검사를 시행하지는 않았다.

감별 진단해야 할 질환으로는 중증 전자간증, Hemolysis, elevated liver enzymes, and low platelets (HELP) 증후군, 혈전성 혈소판 감소 성 자반증, 범발성 혈관내 응고증 등이 있다. 이들 질환은 모두 내피세 포의 손상으로 인한 일련의 결과로 발생하므로 임상 소견이 유사하고, 감별진단이 어렵다. 중증 전자간증 및 HEL 로 발생하며, 심한 고혈압이 동반된다. 중증 전자간증에 합병된 HELP 증후군은 말초혈액도말 검사상 경도의 용혈, 혈청 빌리루빈 상승, $\mathrm{LDH}$ 경도의 상승, 간수치의 상승, 혈소판 감소 소견을 보이는 경우 진단할 수 있다. 중증 전자간증은 신기능의 이상 또는 신경학적 이상소견을 동 반하는 경우는 드물며, PT, aPPT가 경도로 연장될 수 있다[3]. 혈전성 혈소판 감소성 자반증의 일관된 특징은 중증 이상의 심각한 용혈성 빈 혈이며, 혈소판 감소, $\mathrm{LDH}$ 의 증가, antithrombin Iㅢㅇㅢ 감소가 중증 전자간 증과 HELLP 증후군보다 심각하게 나타난다[13]. 범발성 혈관내 응고증 은 보통 패혈증 증세가 동반이 되며, 저혈압을 동반하는 경우가 많고 빈 혈의 정도는 용혈성요독증후군보다 경하게 나타나고, PT, aPPT가 연장 되는 것으로 감별할 수 있다. 상기 환자의 경우 처음에는 중증의 임신중 독증을 의심하였으나, 중증의 임신 중독증 소견을 보이면서 혈뇨와 핍 뇨가 심하고, 빈혈과 심한 혈소판감소증, 그리고 BUN/Cr의 증가, AST/ ALT수치가 정상이고 응고수치가 정상범위여서 중증 전자간증에 동반된 용혈성요독증후군으로 진단하였다.

용혈성요독증후군은 과거 치료를 하지 않을 경우 $90 \%$ 의 사망률을 보 였으나 최근 치료법의 개선으로 생존율이 현저히 개선되어 1979년부터 1990년까지 용혈성요독증후군으로 치료 받은 108 명의 환자에서 $9 \%$ 의 사망률이 보고된 바 있다[14]. 급성기 치료는 무엇보다 적절한 보조요법 이 중요하며 심한 급성신부전에서는 조기에 투석을 실시하는 등의 적극 적인 치료가 예후에 중요한 영향을 미친다. 농축 적혈구와 혈소판의 수 혈, 고혈압 조절 및 경련치료, 신부전에 동반될 수 있는 전해질, 수분의 불균형에 대해 적절한 교정을 해 주고, 헤파린을 투여하는 것이 중요하 다. 신선 냉동 혈장주입과 혈장교환은 prostacyclin stimulating factor의 활성을 보충하고 혈소판 응집 인자 등의 억제, 혈전 생성으로 인해 소모 된 fibrinectin의 보충, 내피 독성인자들을 중화시킬 수 있어 혈소판 수치 가 정상으로 회복되고 용혈이 중지될 때까지 사용한다. 본 증례의 경우 에는 급성 신부전에 대하여 전해질 및 수분 교정 및 혈압 조절 등의 보 조요법을 시행하였으며, 혈전 형성의 방지를 위해 헤파린을 투여하였다. 신기능 회복이 조기에 되지 않을 경우 투석과 혈장 교환술을 시행하려 했으나, 다행히 수술 직후 빠른 신기능의 회복과 함께 용혈성 빈혈의 호 전 및 전신상태의 회복을 보였다.

용혈성 요독 증후군은 소아에서는 비교적 예후가 좋으나 성인에서는 예후가 좋지 않아 약 $15 \%$ 에서는 만성신부전으로 진행한다고 알려져 있 다. 또한 약 $40 \%$ 에서 첫 발생 후 1-140개월에 재발을 경험한다고 알려 져 있고 재발 시 사망률은 $30 \%$ 이상이다. 분만 후 용혈성요독증의 예후 로는 사망률이 $60 \%$ 에 이르며, $12 \%$ 에서 지속적인 투석요법이 필요하고 단지 $9.5 \%$ 에서만 정상으로 회복된다고 알려져 있다[15]. 저자들은 임신 


\section{KOREAN JOURNAL OF OBSTETRICS \& GYNECOLOGY}

Hye-Ji Jeon, et al. Atypical hemolytic uremic syndrome in a patient with preeclampsia

34 주에 임신중독증 임신부에 발생한 용혈성요독증후군 1예를 경험하여 태아심박동 저하로 제왕절개수술 후 수혈, 혈압조절, 헤파린 투여 등의 보전적 요법으로 치료하였기에 문헌 고찰과 함께 보고하는 바이다.

\section{References}

1. Gasser C, Gautier E, Steck A, Siebenmann RE, Oechslin R. Hemolytic-uremic syndrome: bilateral necrosis of the renal cortex in acute acquired hemolytic anemia. Schweiz Med Wochenschr 1955;85:905-9.

2. Noris M, Remuzzi G. Atypical hemolytic-uremic syndrome. N Engl J Med 2009;361:1676-87.

3. Sibai BM, Kustermann L, Velasco J. Current understanding of severe preeclampsia, pregnancy-associated hemolytic uremic syndrome, thrombotic thrombocytopenic purpura, hemolysis, elevated liver enzymes, and low platelet syndrome, and postpartum acute renal failure: different clinical syndromes or just different names? Curr Opin Nephrol Hypertens 1994;3:436-45.

4. Coratelli P, Buongiorno E, Passavanti G. Endotoxemia in hemolytic uremic syndrome. Nephron 1988;50:365-7.

5. Lazebnik N, Jaffa AJ, Peyeser MR. Hemolytic-uremic syndrome in pregnancy. Review of the literature and report of a case. Obstet Gynecol Surv 1985;40:618-21.

6. Shin HC, Lee JJ, Shin YK, Koh SY, Nam KH, Lee KH, et al. A case of postpartum hemolytic uremic syndrome. Korean J Obstet Gynecol 1993;36:3144-8.

7. Kim KH, Lee MS, Sim H, Ahn SH, Song JH, Park DS, et al. A case of hemolytic uremic syndrome developed after voluntary abortion at the sixth weeks of pregnancy. Korean J Med 2003;64:588-92.

8. Koster F, Levin J, Walker L, Tung KS, Gilman RH, Rahaman MM, et al. Hemolytic-uremic syndrome after shigellosis. Relation to endotoxemia and circulating immune complexes. N Engl J Med 1978;298:927-33.

9. Agarwal A, Mauer SM, Matas AJ, Nath KA. Recurrent hemolytic uremic syndrome in an adult renal allograft recipient: current concepts and management. J Am Soc Nephrol 1995;6:1160-9.

10. Ford PM, Levison DA, Down PF, McConnell JB. Clinicopathological spectrum of late postpartum renal failure; two contrasting cases. J Clin Pathol 1976;29:101-10.

11. Oláh KS, Gee H. Postpartum haemolytic uraemic syndrome precipitated by antibiotics. Case report. Br J Obstet Gynaecol 1990;97:83-6

12. Schwartzman MS, D'Agati V. Glomerular annular-tubular immune deposits in adult hemolytic uremic syndrome. Nephron 1988;50:371-5.

13. Martin JN Jr, Bailey AP, Rehberg JF, Owens MT, Keiser SD, May WL. Thrombotic thrombocytopenic purpura in 166 pregnancies: 1955-2006. Am J Obstet Gynecol 2008;199:98-104.

14. Misiani R, Appiani AC, Edefonti A, Gotti E, Bettinelli A, Giani $M$, et al. Haemolytic uraemic syndrome: therapeutic effect of plasma infusion. Br Med J (Clin Res Ed) 1982;285:1304-6.

15. Neild GH. Haemolytic uraemic syndrome. Nephron 1991; 59:194-200.

\section{임신중독증 환자에서 생긴 비전형적인 용혈성요독증후군 1예}

\section{순천향대학교 의과대학 ${ }^{1}$ 산부인과학교실, ${ }^{2}$ 진단검사의학과교실}

전혜지, 현혜선', 이미라, 최슬아', 김윤숙', 배동한, 김휘준 ${ }^{2}$

성인에서 발생하는 비전형적인 용혈성요독증후군은 미세혈관성 용혈성 빈혈, 혈소판감소증, 신장의 미세혈류 혈소판 혈전에 의해 발생하 는 급성 신부전증 등의 특징적인 임상증상이 대장균에 의한 독소와 무관하게 나타나는 위험한 질환이다. 원인은 자간증, 태반박리, 양수합 병증과 같은 임신 합병증을 포함한 다양한 스트레스이며, 치료는 헤파린과 혈장교환으로 이로 인해 최근 생존율이 급격히 향상되었다. 저 자들은 최근 임신 34주에 핍뇨와 혈뇨, 용혈성 빈혈, 혈소판감소증을 보인 임신중독증 임신부에서 태아심박동 저하로 응급 제왕절개수술 후 수혈과 알부민 및 헤파린 치료 후 신기능을 회복한 비전형적인 용혈성요독증후군을 경험하였기에 간단한 문헌 고찰과 함께 보고하는 바이다.

중심단어: 비전형적 용혈성요독증후군, 임신중독증, 임신 